\title{
International Differences Between Big Four Auditors and Their Smaller Counterparts in Monitoring Earnings Management
}

\author{
Xinhua Wang (Corresponding author) \\ International Business Faculty, Beijing Normal University, Zhuhai \\ No 18 Jinfeng Road,Tangjiawan, Zhuhai City, China \\ Tel: 756-6126744Ｅ-mail: lgtybb@ polyu.edu.hk
}

\section{Bibo Yang}

Graduate School of Business, The Hong Kong Polytechnic University

Hung Hom, Kowloon, Hong Kong

Tel: 852-27665087 E-mail: lgtybb@inet.polyu.edu.hk

Received: July 03, 2012 Accepted: August 01, 2012 DOI: 10.5296/ijafr.v2i2.2086

\begin{abstract}
Earnings management that misrepresents the firm's financial picture and misleads investors is a persistent problem. One role of the auditor is to efficiently monitor the accounting reports so as to better inform investors as to the true status of the firm and help close the asymmetric information gap between owners and management. Auditors, however, operate within the constraints of social and legal environments that often display vast international differences. Using sample data from around 50,000 firm-year observations in 42 countries, the paper shows that in the United States the Big Four auditors more effectively monitor overstated earnings than their smaller counterparts, while elsewhere they tend to be more effective in monitoring both overstated and understated earnings. An important policy implication of the results is that uniform worldwide audit and financial reporting standards may not be as effective as might be hoped, because international differences in ownership structures and the resultant agency issues create different reporting incentives.
\end{abstract}

Keywords: Iinternational difference; big auditors; earnings management 


\section{$\triangle$ Macrothink}

International Journal of Accounting and Financial Reporting

\section{Introduction}

The California energy crisis that ushered in the new millennium and brought about the Sarbanes-Oxley Act of 2002, in tandem with the 2008-2009 worldwide financial crisis that made "bailout" an international byword, also moved adverse selection and moral hazard from esoteric academic journals onto the front pages of even the most reader-friendly newspapers. In both instances, considerable blame can be placed on misleading and misstated financial statements, and managements that failed to provide owners and potential investors with a true picture of the firms' financial situations and risk portfolios.

Earnings management, in particular, occurs for a variety of reasons, including management's desire to dampen owners' immediate expectations, which could lead to understated earnings reports, or its desire to encourage an infusion of capital into the firm, which could lead to overstated reports. In either case, the role of the auditor is to set the record straight and to assure the public that the firm's financial statements are in accordance with acceptable accounting standards and are reflective of the firm's actual financial status. But should public confidence in those audited statements depend upon the firm that is doing the auditing, and, in particular, might one expect a Big Four auditor to be any more or less effective than its smaller counterparts in the monitoring process? Still further, (a) are there international differences in the monitoring effectiveness of the Big Four versus the others, and (b) do those differences extend to whether managements are overstating or understating earnings?

The purpose of this paper is to provide answers to these questions - answers that are especially timely in light of the public's well-justified scepticism of the information that managements are providing to them, whether management is that of an investment bank or one of the Big Three U.S. automakers. The answers are provided through regression analyses that, based upon a sample set of around 50,000 observations from 42 countries, show that there are indeed differences in monitoring effectiveness between the Big Four and other auditors, and that these differences depend upon whether management has income-increasing or income-decreasing incentives, and, moreover, that the differences differ internationally.

Specifically, it is shown that in the United States the Big Four auditors more effectively monitor overstated earnings than do their smaller counterparts, while elsewhere they tend to be more effective in monitoring both overstated and understated earnings. An important policy implication of the results is that uniform worldwide audit and financial reporting standards may not be as effective as might be hoped, because international differences in ownership structures and the resultant agency issues create different reporting incentives.

The rest of the paper is organised as follows. The next section reviews previous research and illustrates the contributions of this research. Section 3 presents the statistical model and hypotheses. Section 4 describes the sample, while section 5 reports the results of main tests and sensitivity tests and section 6 concludes this paper.

\section{Background}

\subsection{Focus on accounting accruals choice to manage earnings}

Although firms can manipulate earnings by both real operating and financial reporting choices, this study focuses on the discretions that the insiders exercise in determining reported earnings (i.e. discretionary or abnormal accruals) for two reasons. First, auditors do 


\section{Ml Macrothink}

International Journal of Accounting and Financial Reporting

ISSN 2162-3082

2012, Vol. 2, No. 2

not participate in operating or investing decisions and thereby auditors are irrelevant regarding detection of earnings management by real operating or investing decisions. Auditors, however, have both incentives and resources to detect misreported earnings by the insiders' discretionary accounting choices, because they are legally responsible for certifying whether the financial reports represent fairly, in all material respects, the financial situation and operation results of the firm according to respective accepted accounting principles. Second, discretionary accruals are likely to be a particularly attractive vehicle for insiders to manage reported income because it is less costly than the use of real operating decisions (Haw et al., 2004).

\subsection{Literature review}

Detecting and unravelling the implication of earnings management by outside investors is a daunting task. Most outside investors are not likely to have the resources and expertise to collect relevant information to monitor insiders' financial reporting choices. To mitigate this problem, auditors, big auditors in particular, are hired as an important external monitoring mechanism against accounting discretion choices, which misrepresent earnings. Auditors have both the resources and expertise to unravel the earnings management. Prior studies indicate that capital markets perceive big auditors as an external corporate governance mechanism in both U.S. (e.g. Teoh and Wong, 1993) and the other parts of the world (Fan and Wong, 2005).

A stream of U.S. research shows that big auditors constrain aggressive earnings management. For example, Francis et al. (1999) and Becker et al. (1998) provide evidence that big auditor clients have smaller abnormal accruals. Francis and Krishnan (1999) reported that big auditors are more likely to issue going concern opinions than non-big auditors. The reason why big auditors in the U.S. provide a high quality monitoring role is that they impose high quality earnings to protect against litigation and loss of reputation which can arise from misleading financial reports by clients, in particular overly optimistic earnings reports (DeAnglo, 1981; Kim et al., 2003).

Do big auditors play a monitoring role outside U.S.? Outside U.S., almost all countries have regulatory bodies in place to oversee the activities of auditors. Moreover, auditors do face a risk of prosecution although the frequency of lawsuits is lower in other countries compared with the U.S. ${ }^{1}$. To the extent that the government supervision and litigation works, big auditors have incentives to monitor earnings management. Francis et al. (2003) and Francis and Wang (2008) provide empirical evidence that big auditors provide higher quality audits in countries with strong investor protection than in countries with weak investor protection. These studies, however, do not provide answers on whether external auditors play a governance role even in a weak legal environment. Fan and Wong (2005) fill the void by using a sample of firms from eight East Asia countries with relatively weak investor protection. They document that firms with an agency problem embedded in its ownership structures (i.e. voting rights exceed cash flow rights) are more likely to hire big auditors and consequently big auditor clients receive smaller share price discounts caused by agency conflicts. Using data from 39 countries, Choi and Wong (2007) find that the demand on big auditors by equity issuers is greater in weak legal environments than in strong legal environments. In weak investor protection environments, controlling owners can gain 
investors' confidence and attract capital by hiring external independent auditors, big auditors in particular, as credible monitoring and bonding mechanisms to assure the minority shareholders that their interests would be protected.

In summary, previous studies show that big auditors are part of monitoring mechanisms in countries where the investor protection is strong or weak. These studies give an impression that there are no international differences between big auditors and non-big auditors in monitoring financial reports. This paper argues that big auditors' monitoring mechanism is different between countries because of different reporting incentives, which are caused by international differences in ownership structures and resultant agency issues.

\subsection{International difference of big auditors' monitoring in the earnings management}

Reporting incentives are different between U.S. and other countries because the agency problems are distinctly different between the U.S. and other countries. In the U.S., the agency problem exists between outsider investors and managers. Shareholders of widely held corporations rely on earnings reported by managers to make investment and management hiring/firing decisions. These managers, who operate and manage the firm on a daily basis, have distinct reporting incentives contingent on firm performance. In times of poor performance, managers have an incentive to boost present day earnings by borrowing future earnings to reduce the likelihood of dismissal; while in times of good performance, managers have an incentive to save earnings for use in the future poor times. Managers do so because current performance carries more weight on management tenure decision based on income smoothing and information decay theory (Fudenberg and Tirole, 1995). Consequently, shareholders are very likely to suffer losses if they base their investments on the reported earnings when managers inflate earnings in case of relatively poor performance. As a result of litigation risk and reputation concern, big auditors monitor earnings management more effectively when their clients have income-increasing incentives in the U.S..

In non-U.S. countries, the agency problem comes from the conflicts between controlling and minority shareholders because ownership concentration and separation of cash flow and control rights widely exist in these countries (Claessens et al. 2000; Faccio and Lang, 2002). Controlling shareholders, sometimes the management as well, have inside information and actually decide how the firms operate. The separation of cash flow and control rights provide incentives for controlling shareholders to engage in earnings management to cover their expropriation on minority shareholders. Haw et al. (2004) provide support for this by documenting a significant positive association between absolute value of discretionary accruals and control-ownership divergences, using a sample of firms from 9 East Asian and 13 Western European countries. Moreover, controlling shareholders manage earnings in cases of different reporting incentives contingent on firm performance. Specifically, when current relative performance is good, controlling shareholders have incentives to engage in income-decreasing earnings management to cover their stealing or tunnelling behaviour; when current relative performance is poor, controlling shareholders may even have incentives to boost earnings via income-increasing earnings management to avoid bankruptcies or debt covenant violation so that they can steal in the future. Since minority shareholders can not access inside information and rely on the publicly reported earnings in stock valuation and investment decisions, they suffer losses when controlling shareholders manage reported 
earnings to cover wealth stealing behaviour in times of relatively good performance and when controlling shareholders inflate reported earnings in times of poor performance. To the extent that external government supervision and litigation is sufficient for auditors to provide quality audits, big auditors monitor earnings management when their clients have either income-increasing or income-decreasing incentives in the non-U.S. countries.

This study finds that big auditors constrain earnings management in the U.S.; while big auditors do not play a monitoring role on earnings management in non-U.S. countries. The study, however, finds that the results are dramatically different with consideration of financial reporting incentives: big auditors are more effective than their smaller counterparts in monitoring earnings management only when firms have income-increasing reporting incentives in the U.S.; while big auditors are more effective than their smaller counterparts in monitoring earnings management in cases of both income-increasing and income-decreasing reporting incentives in the non-U.S. countries ${ }^{2}$.

This paper contributes to the literature of big auditors' monitoring in earnings management on two aspects. First, the paper shows that financial reporting incentives have moderating effects on big auditors' monitoring on earnings management, which is missing in the previous cross-country studies. Second, this study shows the international difference on big auditors' monitoring in earnings management and extends the existing literature by documenting this issue. That is, big auditors constrain earnings management only when firms have income-increasing reporting incentives in the U.S.; while big auditors play a monitoring role on earnings management when firms have either income-increasing or income-decreasing reporting incentives.

\section{Statistical model and hypotheses}

\subsection{Earnings management proxies}

We use a firm-specific abnormal accruals to capture earnings management as in Francis and Wang (2008)'s international study. Hereafter, it is referred as DeFond and Park abnormal accruals since it is originated from DeFond and Park (2001). In the sensitivity test, we measure abnormal accruals by Jones (1991) or various modifications of Jones' model.

DeFond and Park abnormal accruals of a firm are the difference between total accruals and expected accruals. The expected accruals, assumed to follow the linear expectation, are proportional to sales and gross property plant and equipment (hereafter PPE), and the proportion is the same as the prior year in terms of the ratio of current accruals to sales and the ratio of depreciation expenses to PPE. Francis and Wang (2008) illustrate how to calculate this firm-specific abnormal accruals: assuming the ratio of current accruals to sales is 0.15 for a firm in year $t-1$, based on prior year sales of $\$ 100$ and prior current accruals of $\$ 15$; if sales in year $t$ is $\$ 120$, the predicted current accruals of year $t$ will be $\$ 120 \times 0.15=\$ 18$; the same procedure applies to the predicted depreciation based the prior year's ratio of depreciation to gross PPE. The advantage of this proxy is that it implicitly controls cross-country differences in accounting standards by using the firm itself as its own control in calculating abnormal accruals.

Using data from Compustat Global Industrial and Commercial file, we calculate predicted accruals and abnormal accruals as follows: 


\section{Macrothink}

International Journal of Accounting and Financial Reporting

Predicted accruals $=\{[$ Sales $(\# 1)$ in year $\mathrm{t} \times($ current accruals in year $\mathrm{t}-1 /$ sales in year $\mathrm{t}-1)]-$ [gross PPE (\#77) in year $\mathrm{t} \times$ (depreciation in year t-1(\#11-\#13)/gross PPE in year t-1(\#77)] total assets (\#89) in year t-1;

Abnormal accruals $=$ Total accruals - predicted total accruals.

Total accruals, earnings before extraordinary items, operating cash flows and current accruals are defined by the following:

Total accruals $=\{$ Earnings before extraordinary items - Operating cash flows $\} /$ total assets (\#89) in year t-1;

Earnings before extraordinary items = net income $(\# 32)$ - extraordinary items $(\# 33)$;

Operating cash flows = earnings before extraordinary items (as above) + depreciation and amortization (\#11) + change of deferred income tax (\#105) + change of untaxed reserve $(\# 108)+$ change in other liabilities (\#109) + minority interest (\#27) - current accruals (as defined below) ${ }^{3}$;

Current accruals $=$ change in non-cash working capital $=\Delta[$ total current assets $(\# 75)-$ cash and short term investment (\#60) - treasury stock shown as current asset (\#73)] $-\Delta$ [total current liabilities(\#104) - total amount of debt in current liabilities (\#94) - proposed dividends(\#102)].

\subsection{Current relative performance measure and financial reporting incentives}

Based on Fudenberg and Tirole (1995), we measure firms' current relative performance by the difference between operating cash flows in the current-year divided by lagged total assets (hereafter CFO) and prior- year CFO. If the current CFO is greater (less) than the prior-year $\mathrm{CFO}$, it is defined as good (poor) current relative performance, i.e. income-decreasing (income-increasing) reporting incentives. In the sensitivity tests, industry median CFO is also used as the performance benchmark to measure relative performance and the results are qualitatively same.

3.3. The regression model used in testing the association between discretionary accruals and big auditors

Based on Francis and Wang (2008), the following model is used to test the association between abnormal accruals and big auditors.

$D A C=\alpha_{0}+\beta_{1} B i g 4+\beta_{2} I S A L E S+\beta_{3} C F O+\beta_{4} L E V+\beta_{5} G R O W T H+\beta_{6} \triangle P P E+$

$\beta_{7} L A G_{-} L O S S+$ fixed effects $+\varepsilon$ 
where for each firm year:

\begin{tabular}{|l|l|l|}
\hline DAC & $=$ & abnormal accruals \\
\hline Big4 & $=$ & $\begin{array}{l}\text { dummy variable, equal to } 1 \text { if firm is audited by a big } \\
\text { auditor }\end{array}$ \\
\hline ISALES & $=$ & log of clients sales in \$ millions \\
\hline CFO & $=$ & $\begin{array}{l}\text { operating cash flow for firm i in year t scaled by lagged } \\
\text { total assets }\end{array}$ \\
\hline LEV & $=$ & total liabilities/total assets \\
\hline GROWTH & $=$ & $\begin{array}{l}\text { sales growth rate, defined as the sales in year t minus sales } \\
\text { in } \mathrm{t}-1 \text { and scaled by sales in year t-1 }\end{array}$ \\
\hline$\Delta$ PPE & $=$ & $\begin{array}{l}\text { growth rate of gross property plant and equipment, defined } \\
\text { as PPE in year t minus PPE t-1 and scaled by PPE t-1 }\end{array}$ \\
\hline LAG_LOSS & $=$ & $\begin{array}{l}\text { dummy variable, equal to 1 if firm reports negative } \\
\text { income before extraordinary items in year t-1 }\end{array}$ \\
\hline Fixed effects & $=$ & industry and year effects \\
\hline$\varepsilon$ & $=$ & Random-error term \\
\hline
\end{tabular}

The above fixed effects model uses year-specific dummy variables to control for systematic time period effects and two-digit SIC industry-dummies to control for industry effects. Other control variables are added based on prior research (e.g. Becker et al., 1998): 1) firm size (ISALES), measured by nature log of total sales, because prior studies document that large firms tend to have lower level of accruals than small firms; 2) operating cash flow deflated by lagged total assets (CFO) because of the well-documented inverse relation between operating cash flow and accruals; 3) leverage (LEV), for higher leverage creates the incentive to increase reported earnings to avoid debt covenant violation; 4) sales growth (GROWTH) and PPE growth ( $\triangle \mathrm{PPE})$ due to firm growth affecting accruals; 5) prior year losses dummy (LAG_LOSS), proxy for financial distress and bankruptcy risk and therefore an incentive to increase reported earnings in the subsequent year.

The main test variable is an indicator variable of big auditors, which is equal to one when the firm is a client of the big 4 auditors; zero otherwise. If big auditors are more effective in constraining earnings management for firms with income-increasing (income-decreasing) reporting incentives, $\beta_{1}$ is significantly negative (positive). In this study, we hypothesize:

Hypothesis 1 (H1): $\beta_{1}$ is significantly negative for firms with income-increasing reporting incentives in the U.S. sample.

Hypothesis 2 (H2): $\beta_{1}$ is insignificant for firms with income-decreasing reporting incentives in the U.S. sample.

Hypothesis 3 (H3): $\beta_{1}$ is significantly negative for firms with income-increasing reporting incentives in the non-U.S. sample. 
Hypothesis 4 (H4): $\beta_{1}$ is significantly positive for firms with income-decreasing reporting incentives in the non-U.S. sample.

\section{The sample}

We obtain the sample and financial data from the WRDS (Wharton Research Data System) Compustat Global Industrial and Commercial file for the period from 1994 to 2004. Following Francis and Wang (2008), we exclude firm-year observations with non-fully consolidated financial statements, those not audited and those with missing values for the dependent and independent variables. Next we exclude observations of Financial Institutions (SIC 6000-6999). We further delete observations from Japan, South Korea, India and Pakistan for potential mis-coding of the auditor identification because big auditors in these countries practise through the names of their local affiliates and thus there is no precise way of determining which firms are audited by big auditors (Francis and Wang, 2008) ${ }^{4}$. Finally, we exclude observations that fall in the top and bottom $1 \%$ of abnormal accruals and observations with absolute value of studentized residuals greater than 3 in the abnormal accruals analysis. After these screens, there are 49,314 firm-year observations for the period 1996 to 2004 when DeFond and Park abnormal accruals are used as the measure of earnings management ${ }^{5}$. These sample size are smaller than 57,966 of Francis and Wang (2008) because the prior year CFO available is required.

\section{<Table 1 here>}

Table 1 presents the number of firm-year observations for each of the 42 countries. Among these countries, 12 countries have less than 100 firm year observations, 21 countries have from 100 to 1000 firm year observations, and 9 countries have more than 1000 firm year observations. Table 1 shows that big auditors' market share at country level ranges from $28 \%$ in the Philippines to $100 \%$ for Kenya, which has 5 observations in total.

\section{$<$ Table 2 here>}

Table 2 reports the results of the univariate tests respectively for the sub-sample of income-increasing reporting incentives and the sub-sample of income-decreasing reporting incentive for both U.S. firms and non-U.S. firms. Table 2 shows that big auditors' clients have significant smaller discretionary accruals in terms of magnitude than non-big auditors' clients regardless of income-increasing or income-decreasing reporting incentives in both the U.S. and non-U.S. countries. We attribute the significant smaller magnitude of discretionary accruals for the U.S. sample with income-decreasing reporting incentives to significant differences in sales growth and insignificant differences of operating cash flows between big and no-big auditors' clients in this sample ${ }^{6}$.

Univariate tests on control variables give the similar results using different earnings management proxies. Table 2 shows that big auditor clients are larger firms in term of sales, have better operating performance in term of operating cash flows, lower leverage (with exception of U.S. firms with income-increasing incentives), higher sales growth and PPE growth and are less likely to have incurred a loss in the prior year. This indicates that the self-selection is an issue because the differences between big auditors and their smaller 
counterparts can be attributed to client characteristics (Lawrence et al., 2011). Since the self-selection may lead to finding the association between earnings management and big auditors, we address the self-selection issue in details in the sensitivity test.

\section{Empirical results}

\subsection{Main empirical results}

$<$ Table 3 here>

Table 3 presents the regression results. For brevity, we do not report the coefficients of year and industry dummies. Following Francis and Wang (2008), we use the procedure of Rogers (1993) to calculate t-statistics and p-values. Rogers (1993) procedure produce robust t-statistics and p-values, which control for country clustering effects and common variance among observations within a particular country in addition to heteroscedasticity control ${ }^{7}$.

Table 3 shows a negative and significant coefficient ( $-0.008, \mathrm{p}$ value of 0.03 ) on the dummy variable of big auditors in the U.S. sample. Further analyses show that the negative and significant coefficient $(-0.02, \mathrm{p}$ value of less than 0.01$)$ on the indicator variable of big auditors only exists in the sub-sample of firms with income-increasing reporting incentives, supporting hypothesis 1 . Table 3 reports an insignificantly negative coefficient on the indicator variable of big auditors in the non-U.S. sample, which supports hypothesis 2. Further analyses, however, show a negative and significant $(-0.011, \mathrm{p}$ value of less than 0.01$)$ coefficient on the indicator variable of big auditors in firms with income-increasing reporting incentives in the non-U.S. sample, supporting hypothesis 3. Meanwhile, the results show a positive and significant coefficient $(0.007, \mathrm{p}$ value of 0.001$)$ on the indicator of big auditors in firms with income-decreasing reporting incentives, supporting hypothesis 4 . The overall results of table 3 show that financial reporting incentives improve the power to find the significant association between abnormal accruals and big auditors in the non-U.S. firms.

In summary, table 3 shows that in the U.S., big auditors are more effective than non-big auditors in monitoring clients' discretionary accounting choices when their clients have income-increasing reporting incentives; while big auditors are not different from their smaller counterparts in monitoring clients' discretionary accounting choices when their clients have income-decreasing reporting incentives. In other countries, big auditors are more effective than their smaller counterparts in monitoring discretionary accounting choices when their clients have either income-decreasing or income-increasing reporting incentives.

\subsection{Tests of robustness}

We conduct several robust tests to investigate whether results are sensitive to different measures of abnormal accruals and to rule out alternative explanations. First, this study measures abnormal accruals using Jones' model (1991). The results are qualitatively similar ${ }^{8}$. Haw et al. (2004) defend the use of this measure in their international study by pointing out factors that potentially influence normal accruals vary significantly across industries.

Second, the unreported results using the industry median CFO as the performance benchmark are qualitatively unchanged ${ }^{9}$.

Third, to address the concern of the countries with smaller numbers of observations driving 
the results, this study reruns the regressions with countries of at least 1000 observations. Unreported results show that previously documented relations are qualitatively unchanged using only countries with more than 1000 firm-year observations.

\section{<Table 4 here>}

Fourth, Francis and Wang (2008) provide evidence that big auditors in strong investor protection countries impose high earnings quality on clients. To check whether the results documented is concentrated in strong investor protection countries, this study reruns the regressions in the strong and poor investor protection countries separately for the non-U.S sample. Specifically, this study uses two different ways to group countries as strong/weak investor protection: 1) a country is a strong (weak) investor protection country if the anti-director rights index is above (below) the median; 2) a country is a strong (weak) investor protection one if it is a common (code) law country. The common law and anti-director rights index produce qualitatively similar results. To save space, table 4 reports only the results using anti-director rights as a proxy for investor protection. The results of table 4 show that previous significant findings exist only in the strong investor-protection countries.

Fifth, the study does robust analyses to ease the concern whether the indicator variable of big auditor actually acts as a proxy for firms' control and ownership wedge because Fan and Wong (2005) provide empirical evidence that firms with control and cash flow wedge are more likely to hire big auditors. To address the concern that the big auditors may act as a proxy for the control and ownership wedge, this study reruns the regression controlling for control and ownership wedges using 13 western European countries and 9 East Asia countries, with these wedge data available from Claessens et al. (2000) and Faccio and Lang (2002). Unreported results show that the coefficient on the indicator variable of big auditors is positive and significant (negative and significant) in the sub-sample of firms with income-decreasing (income-increasing) incentives controlling for the control and ownership wedge. Using Jones' model abnormal accruals and industry median CFO as the performance benchmark instead, results are qualitatively unchanged. This result rules out that the indicator of big auditors acting as proxies for control and ownership wedge.

Sixth, Choi and Wong (2007)'s international study documents that firms with equity issuance are more likely to hire big auditors. To rule out that the results are driven by firms issuing equity, this study reruns the previous analyses for firms with equity issuance and firms without equity issuance, where equity issuers are defined as firms that issue shares or long-term debt in the prior year. Unreported results show that the previous results exist in both sub-samples of the equity-issuers and the non-equity-issuers. This study does not use share-increasing and share-decreasing transactions as Kim et al. (2003) do to act as a proxy for income-increasing and income-decreasing incentives in the sensitivity tests because the sample size reduces dramatically to 3,186 firm-year observations requiring two-consecutive-year outstanding shares available to calculate share increases/decreases.

$<$ Table 5 here> 
Seventh, the two-stage Heckman treatment effect model can not be used to address the self-selection issue because there is a high level of multicollinearity between the inverse Mills ratios and big auditor dummy. The variance inflation factor on the inverse Mills ratios is about 20 in the U.S sample and around 97 in the non-U.S. sample. Adding the inverse Mills ratios in the second stage causes the sign on the indicator of big auditors change.

This study instead attempts to address the self-selection issue by examining whether the impact of external investor protection mechanism on discretionary accounting choices differ between big auditors' clients and non-big auditors' clients, contingent on income-decreasing/income-increasing reporting incentives. Although this approach can not rule out the self-selection issue completely, it does provide evidence that the findings of this study is not solely driven by the self-selection because the external investor protection plays a monitoring role on the discretionary accounting choices only through big auditors, based on the additional tests. Following Francis and Wang (2008), this study uses five measures of country level investor protections: 1) common law dummy; 2) the anti-director rights index; 3) the disclosure index; 4) the litigation index; 5) the public enforcement index ${ }^{10}$. Using Jones' model abnormal accruals and industry median CFO as the performance benchmark produces similar results. We only report the results using the DeFond and Park abnormal accruals and prior year CFO as the performance benchmark for brevity. Consistent with Francis and Wang (2008), the results of table 5 show that investor protections constrain earnings management only for big auditor clients, but not for non-big auditor clients. This supports the belief that non-big auditors do not respond to the legal incentives as big auditors because they do not have the same reputation capital at risk as big auditors and hence do not have as strong an incentive to enforce higher earnings quality.

In summary, the sensitivity tests show that the results are not sensitive to alternative earnings management measures. Nevertheless, the additional tests can not completely rule out the self-selection as an alternative explanation.

\subsection{Economic magnitude}

To compute the economic magnitude of the impact of big auditors on constraining earnings management for the non-U.S. sample, this study reports a percentage effect on the earnings. Based on the coefficients from table 3 Panel B, big auditors reduce the magnitude of abnormal accruals by $16.74 \%(16.74 \%=0.007 \times 455.065 \div 19.032)$ of the median pre-tax earnings for the non-U.S. firms with income-decreasing reporting incentives. Meanwhile, big auditors reduce the magnitude of abnormal accruals by $26.95 \%(26.95 \%=0.011 \times 411.640$ $\div 16.805$ ) of the median pre-tax earnings for the non-U.S. firms with income-increasing reporting incentives ${ }^{11}$.

\section{Conclusions}

This study is the first one which investigates and documents the international difference between big auditors and non-big auditors in monitoring earnings management. Based on the ownership structure and agency problem literature and financial reporting incentives, this study develops a prediction on the international difference between big auditors and non-big auditors in monitoring earnings management. Furthermore, this study finds that big auditors curb earnings management only when their clients have income-increasing reporting 


\section{MInstitute Macrothink $_{\text {Int }}$}

International Journal of Accounting and Financial Reporting ISSN 2162-3082

incentives in the U.S.; while big auditors constrain earnings management when their clients have either income-increasing or income-decreasing reporting incentives. These results, however, do not mean that big auditors monitor earnings management more effectively in other countries than in the U.S.

This study has two limitations. First, the validity of the findings is subject to how the abnormal accruals accurately capture earnings management. Two measures of abnormal accruals produce similar results. This adds assurance that the two measures capture earnings management through discretionary accounting choices. There is, however, considerable controversy on the measure of discretionary accounting choices in the international setting. Second, the study does not rule out the self-selection explanation completely.

Nevertheless, this study is relevant regarding the harmonisation of global auditing and financial reporting standards. This study indicates that the uniform audit and financial reporting standards may not be as effective as expected because the ownership structures and the resultant agency conflicts, which vary around the world, create different reporting incentives.

\section{Acknowledgement}

We presented a previous version of this paper with the title "Is Asymmetric Earnings Management Monitoring by Big Auditors the Same Around the World?" at the American Accounting Association 2008 Annual Conference. We are grateful for the helpful guidance on how to write the revised paper from Professor Ira Howard at Florida University and the insightful suggestions from Professor Kashi R. Balachandran at New York University. We acknowledge the research support from the Hong Kong Polytechnic University.

\section{Notes:}

1. Fan and Wong (2005) cite the prosecution on Ernst and Young by the Hong Kong High Court after its client, Akai Holdings, collapsed with U.S. \$1.72 billion loss.

2. The results show that big auditors constrain income-increasing earnings management in non-U.S. sample, suggesting that controlling shareholders prop when current relative performance is poor.

3. This definition of operating cash flows follows Ali and Hwang (2000) and Francis and Wong (2007), and missing values on deferred income taxes, untaxed reserves and minority interest are treated as zero.

4. Big auditor market share of these four countries close to zero.

5. To compute DeFond and Park abnormal accruals, a company must have observations for at least three consecutive years, so that 1996 is the first test year. The sample observations are 55,258 when Jones' model abnormal accruals are used.

6. Additional tests, however, show that there is no significant difference of discretionary accruals between big auditors' clients and non-big auditors' clients when clients have income-decreasing reporting incentives using Jones' model (1991) abnormal accruals. Jones' model abnormal accruals are calculated as the residuals of the following regression:

TAC $_{t} /$ Asset $_{t-1}=\alpha_{0}+\alpha_{1}\left(1 / A_{t-1}\right)+\beta_{1}\left(\Delta R E V_{t /} A_{t-1}\right)+\beta_{2}\left(P P E_{t} / A_{t-1}\right)+\varepsilon_{t}$

Where variables are defined for each firm year as follows: 


$\begin{array}{lll}\mathrm{TAC} & = & \text { total accruals; } \\ \mathrm{A}_{\mathrm{t}-1} & = & \text { lagged total assets; } \\ \triangle \mathrm{REV} & = & \text { change in sales revenues; } \\ \mathrm{PPE} & = & \text { property, plant and equipment } \\ \varepsilon & = & \text { random-error term }\end{array}$

The regression assumes that parameter estimates on firms' sales and PPE are industry-specific. So it is estimated by each industry (based on two-digit Standard and Industrial Classification codes) in the same year requiring at least 20 observations for each SIC code industry.

7. In this analysis, the sample consists of 42 countries, and it is reasonable to believe observations might be correlated within each country (intra-cluster dependence). The Rogers (1993) approach treats each country as a cluster and estimates the variance as if there were only 42 observations and the corresponding $t$-values have 42 degrees of freedom.

8. The results with Jones' model (1991) abnormal accruals are qualitatively similar except the results of the univariate tests for firms with income-decreasing reporting incentives in both U.S. and non-U.S. samples. Unreported tests also use the abnormal accruals from the Dechow and Dichev (2002) model. In this approach, the abnormal accruals are calculated as the residuals from regressing total accruals on the prior, current and future year CFOs. The abnormal accruals, however, do not produce the expected significant results. A possible explanation is that this abnormal accruals measure is orthogonal with $\mathrm{CFO}$ and thus results in a low level of variation between times of good performance and times of poor performance, where performance is defined using either prior year or industry median CFO as a performance benchmark. Consequently, this results in low power in detecting significant associations between abnormal accruals and the indicator of big auditors.

9. In the tests using industry median $\mathrm{CFO}$, we require at least 3 observations available for each industry in each year within a respective country.

10. Country level common law or code law data is from La Porta et al. (2002). Anti-director rights index is from La Porta et al. (1998); the disclosure, litigation and public enforcement index are from La Porta et al. (2006).

11. For non-U.S. firms with income-decreasing reporting incentives, the median lagged total assets of 455.065 million dollars and the median pre-tax earnings are 19.032 million dollars. Meanwhile, for non-U.S. firms with income-increasing reporting incentives, the median lagged total assets of 411.640 million dollars and pre-tax earnings of 16.805 million dollars. 


\section{Macrothink}

International Journal of Accounting and Financial Reporting ISSN 2162-3082 2012, Vol. 2, No. 2

\section{References:}

Becker, C.L., DeFond, M.L., Jiambalvo, J. and Subramanyam, K.R.. (1998), "The effect of audit quality on earnings management", Contemporary Accounting Research Vol.15 (1): pp. $1-24$.

Berle, A. and Means, G. (1932), The modern corporation and private property, New York: MacMillan.

Choi, J.H. and Wong, T.J. (2007), "Auditors governance functions and legal environments: an international investigation”, Contemporary Accounting Research, Vol.24 (1): pp. 13-46.

Claessens, S., Djankov, S. and Lang, L.H.P. (2000), "The separation of ownership and control in East Asian corporations", Journal of Financial Economics, Vol.58: pp. 81-112.

DeAngelo, L. (1981), “Auditor size and audit quality”, Journal of Accounting and Economics, Vol.3: pp.183-199.

Dechow, P. and Dichev, I. (2002), "The quality of accruals and earnings: the role of accrual estimation error", The Accounting Review, Vol.77: pp.35-59.

DeFond, M.L. and Park, C. (2001), "The reversal of abnormal accruals and the market valuation of earnings surprises", The Accounting Review, Vol.76: pp.375-404.

Faccio, M. and Lang, L.H.P. (2002), "The ultimate ownership of western European corporations", Journal of Financial Economics, Vol.65: pp.365-395.

Fan, J.P.H. and Wong, T.J. (2005), "Do external auditors perform a corporate governance role in emerging markets? Evidence from East Asia", Journal of Accounting Research, Vol.43(1): pp. 35-72.

Francis, J., Khurana, I. and Pereira, R. (2003), "The role of accounting and auditing in corporate governance, and the development of financial markets around the world", Asia Pacific Journal of Accounting and Economics, Vol.10: pp.1-30.

Francis, J. and Krishnan, J. (1999), "Accounting Accruals and auditor reporting conservatism", Contemporary Accounting Research, Vol.16: pp.135-165.

Francis, J., Maydew, E. and Sparks, H.C. (1999), "The role of big 6 auditors in the credible reporting of accruals", Auditing: A Journal of Practice and Theory, Vol.18: pp.17-34.

Francis, J. and Wang D.C. (2008), "The joint effect of investor protection and big 4 audits on earnings quality around the world", Contemporary Accounting Research, Vol.25(1): pp.157-191.

Fudenberg, K. and Tirole J. (1995), “A theory of income and dividend smoothing based on incumbency rents", Journal of Political Economy, Vol.103(1): pp.75-93.

Haw, I.M., Hu B.B., Hwang, L.S. and Wu, W. (2004), "Ultimate ownership, income management, and legal and extra-legal institutions", Journal of Accounting Research, Vol.42(2): pp.423-462.

Hirst, D.E. (1994), "Auditor sensitivity to earnings management", Contemporary Accounting Research, Vol.11(1): pp.405-422.

Jones, J. (1991), "Earnings management during import relief investigation", Journal of Accounting Research, Vol.29(2): pp.193-228. 


\section{Macrothink}

International Journal of Accounting and Financial Reporting

ISSN 2162-3082

Kim, J.B., Chung, R. and Firth, M. (2003), “Auditor conservatism, asymmetric monitoring and earnings management”, Contemporary Accounting Research, Vol.20 (2):pp.323-359.

La Porta, R., Lopez-de-Silanes, F., Shleifer, A. and Vishny, R. (1999), "Law and finance", Journal of Political Economy, Vol.106: pp.1113-1155.

La Porta, R., Lopez-de-Silanes, F., Shleifer, A. and Vishny, R. (1999), “Corporate ownership around the world", Journal of Finance, Vol.54: pp.471-518.

La Porta, R., Lopez-de-Silanes, F., Shleifer, A. and Vishny, R. (2002), "Investor protection and corporate valuation", Journal of Finance, Vol.3: pp.1147-1169.

La Porta, R., Lopez-de-Silance, F. and Shleifer, A. (2006), "What works in securities laws?”, Journal of Finance, Vol.61: pp.1-32.

Lawrence A., Minutti-Meza, M. and Zhang Ping. (2011), "Can Big 4 versus Non-Big 4 Differences in Audit-Quality Proxies Be Attributed to Client Characteristics?", The Accounting Review, Vol.86 (1): pp.259-286.

Rogers, W.H. (1993), "Regression standard errors in clustered samples", Stata Technical Bulletin, Vol.13: pp.19-23.

Teoh, S. and Wong, T.J. (1993), "Perceived auditor quality and the earnings response coefficient", The Accounting Review, Vol.36: pp.346-366. 


\section{$\begin{array}{rr}\text { Macrothink } & \text { International Journal of Accounting and Financial Reporting } \\ \text { ISSN 2162-3082 } \\ \text { Instrtute }\end{array}$}

Table 1

Number of Observations and Big Auditors' Market Shares

\begin{tabular}{|c|c|c|c|c|c|}
\hline Country & $\begin{array}{l}\text { Number of } \\
\text { observations }\end{array}$ & share & Big auditors' market & COMMON & ANTIDIR \\
\hline Argentina & 71 & & $76.83 \%$ & 0 & 4 \\
\hline Australia & 1730 & & $81.71 \%$ & 1 & 4 \\
\hline Austria & 278 & & $48.52 \%$ & 0 & 2 \\
\hline Belgium & 111 & & $64.49 \%$ & 0 & 0 \\
\hline Brazil & 428 & & $90.92 \%$ & 0 & 3 \\
\hline Canada & 2843 & & $93.09 \%$ & 1 & 5 \\
\hline Switzerland & 905 & & $76.34 \%$ & 0 & 5 \\
\hline Chile & 395 & & $87.97 \%$ & 0 & 3 \\
\hline Colombia & 40 & & $50.00 \%$ & 0 & 2 \\
\hline Germany & 2601 & & $47.35 \%$ & 0 & 2 \\
\hline Denmark & 683 & & $86.12 \%$ & 0 & 3 \\
\hline Egypt & 9 & & $50.00 \%$ & 0 & 3 \\
\hline Spain & 127 & & $92.43 \%$ & 0 & 1 \\
\hline Finland & 553 & & $73.95 \%$ & 0 & 2 \\
\hline France & 379 & & $43.25 \%$ & 1 & 5 \\
\hline U.K. & 6605 & & $82.27 \%$ & 0 & 2 \\
\hline Greece & 60 & & $31.91 \%$ & 1 & 4 \\
\hline Hong Kong & 692 & & $89.19 \%$ & 1 & 3 \\
\hline Indonesia & 791 & & $50.42 \%$ & 0 & 1 \\
\hline Ireland & 303 & & $88.85 \%$ & 0 & 1 \\
\hline Israel & 115 & & $49.48 \%$ & 1 & 3 \\
\hline Italy & 694 & & $94.08 \%$ & 1 & 4 \\
\hline Jordan & 3 & & $75.00 \%$ & 0 & 1 \\
\hline Kenya & 6 & & $100.00 \%$ & 0 & 2 \\
\hline LKA & 13 & & $92.86 \%$ & 1 & 4 \\
\hline Mexico & 186 & & $75.54 \%$ & 0 & 4 \\
\hline Malaysia & 3126 & & $65.46 \%$ & 0 & 3 \\
\hline Netherlands & 962 & & $92.00 \%$ & 0 & 3 \\
\hline Norway & 587 & & $92.01 \%$ & 0 & 3 \\
\hline New Zealand & 318 & & $91.82 \%$ & 1 & 4 \\
\hline Peru & 50 & & $72.73 \%$ & 1 & 5 \\
\hline Philippines & 374 & & $28.15 \%$ & 0 & 3 \\
\hline Portugal & 51 & & $34.59 \%$ & 1 & 3 \\
\hline Singapore & 1840 & & $87.27 \%$ & 0 & 3 \\
\hline Sweden & 1285 & & $81.88 \%$ & 0 & 2 \\
\hline Thailand & 1100 & & $36.36 \%$ & 0 & 3 \\
\hline Turkey & 48 & & $82.35 \%$ & 1 & 2 \\
\hline Taiwan & 789 & & $75.79 \%$ & 0 & 2 \\
\hline United States & 17757 & & $93.83 \%$ & 1 & 5 \\
\hline
\end{tabular}


$86.99 \%$

COMMON equals 1 if a country has a common law origin and 0 otherwise, which is from La Porta et al. (2002). ANTIDIR is the anti-director rights index from La Porta et al. (1999).

\section{Table 2}

Univariate Tests between Big Auditors' and Non-Big Auditors' Clients

Panel A: U.S. Sample

income-decreasing incentives ( $\mathrm{CFO}>$ prior year $\mathrm{CFO}$ )

\begin{tabular}{lcccccccc}
\hline & \multicolumn{7}{l}{ Big auditor clients N=8339 } & \multicolumn{2}{c}{ non-Big auditor clients N=581 } & & \\
\cline { 2 - 9 } Variables & Mean & Median & Std Dev & Mean & Median & Std Dev & t value & $\mathrm{z}$ value \\
\hline DAC & -0.052 & -0.040 & 0.112 & -0.068 & -0.058 & 0.144 & 2.58 & 3.99 \\
ISALES & 5.929 & 5.966 & 1.782 & 4.080 & 4.080 & 1.760 & 24.2 & 17.81 \\
CFO & 0.118 & 0.123 & 0.159 & 0.100 & 0.116 & 0.182 & 2.39 & 1.59 \\
LEV & 0.497 & 0.453 & 0.361 & 0.576 & 0.441 & 0.667 & -2.86 & -0.90 \\
GROWTH & 0.173 & 0.102 & 0.366 & 0.116 & 0.064 & 0.381 & 3.64 & 4.25 \\
SPPE & 0.156 & 0.086 & 0.315 & 0.120 & 0.057 & 0.336 & 2.57 & 3.99 \\
LAG_LOSS & 0.339 & 0 & 0.473 & 0.411 & 0 & 0.493 & -3.57 & -3.57 \\
\hline
\end{tabular}

income-increasing incentives ( $\mathrm{CFO}<$ prior year $\mathrm{CFO})$

\begin{tabular}{lcccccccc}
\hline \multicolumn{7}{l}{ Big auditor clients N=8277 } & \multicolumn{7}{c}{ non-Big auditor clients N=560 } \\
\hline Variable & Mean & Median & Std Dev & Mean & Median & Std Dev & t value & z value \\
\hline DAC & 0.041 & 0.025 & 0.106 & 0.064 & 0.049 & 0.133 & -4.01 & -6.03 \\
ISALES & 5.971 & 5.982 & 1.767 & 4.256 & 4.263 & 1.596 & 24.43 & 17.81 \\
CFO & 0.029 & 0.056 & 0.153 & -0.01 & 0.019 & 0.174 & 5.12 & 5.67 \\
LEV & 0.490 & 0.446 & 0.336 & 0.479 & 0.363 & 0.409 & 0.59 & 4.45 \\
GROWTH & 0.116 & 0.074 & 0.327 & 0.076 & 0.046 & 0.303 & 3.01 & 3.66 \\
DPPE & 0.158 & 0.089 & 0.313 & 0.123 & 0.060 & 0.344 & 2.36 & 4.80 \\
LAG_LOSS & 0.209 & 0 & 0.407 & 0.27 & 0 & 0.444 & -3.12 & -3.36 \\
\hline Pan_
\end{tabular}

Panel B: Non-U.S. Sample

\begin{tabular}{|c|c|c|c|c|c|c|c|c|}
\hline \multirow[b]{2}{*}{ Variable } & \multicolumn{3}{|c|}{ Big auditor clients $\mathrm{N}=12030$} & \multicolumn{3}{|c|}{ non-Big auditor clients $\mathrm{N}=3762$} & \multirow[b]{2}{*}{$\mathrm{t}$ value } & \multirow[b]{2}{*}{$\mathrm{z}$ value } \\
\hline & Mean & Median & Std Dev & Mean & Median & Std Dev & & \\
\hline DAC & -0.066 & -0.050 & 0.112 & -0.074 & -0.061 & 0.125 & 3.68 & 5.49 \\
\hline ISALES & 6.177 & 6.099 & 2.125 & 5.769 & 5.667 & 2.305 & 9.65 & 8.07 \\
\hline $\mathrm{CFO}$ & 0.128 & 0.120 & 0.131 & 0.116 & 0.108 & 0.127 & 5.00 & 5.90 \\
\hline LEV & 0.555 & 0.504 & 0.395 & 0.597 & 0.521 & 0.499 & -4.76 & -2.91 \\
\hline GROWTH & 0.106 & 0.069 & 0.327 & 0.084 & 0.056 & 0.342 & 3.50 & 3.03 \\
\hline$\triangle \mathrm{PPE}$ & 0.089 & 0.052 & 0.301 & 0.070 & 0.041 & 0.305 & 3.30 & 4.93 \\
\hline LAG_LOSS & 0.278 & 0 & 0.448 & 0.32 & 0 & 0.467 & -4.94 & -5.05 \\
\hline
\end{tabular}




\begin{tabular}{|c|c|c|c|c|c|c|c|c|}
\hline \multirow[b]{2}{*}{ Variable } & \multicolumn{3}{|c|}{ Big auditor clients $\mathrm{N}=11955$} & \multicolumn{3}{|c|}{ non-Big auditor clients $\mathrm{N}=3810$} & \multirow[b]{2}{*}{$\mathrm{t}$ value } & \multirow[b]{2}{*}{$\mathrm{z}$ value } \\
\hline & Mean & Median & Std Dev & Mean & Median & Std Dev & & \\
\hline DAC & 0.049 & 0.033 & 0.109 & 0.062 & 0.042 & 0.123 & -5.71 & -4.95 \\
\hline ISALES & 6.163 & 6.075 & 2.132 & 5.866 & 5.735 & 2.298 & 7.06 & 6.25 \\
\hline $\mathrm{CFO}$ & 0.031 & 0.049 & 0.133 & 0.012 & 0.030 & 0.131 & 7.57 & 9.56 \\
\hline LEV & 0.559 & 0.499 & 0.418 & 0.597 & 0.508 & 0.516 & -4.23 & -1.94 \\
\hline GROWTH & 0.076 & 0.053 & 0.326 & 0.045 & 0.037 & 0.315 & 5.26 & 3.98 \\
\hline$\triangle \mathrm{PPE}$ & 0.088 & 0.057 & 0.300 & 0.061 & 0.040 & 0.288 & 4.93 & 6.92 \\
\hline LAG_LOSS & 0.183 & 0 & 0.386 & 0.227 & 0 & 0.419 & -5.75 & -5.99 \\
\hline
\end{tabular}

DAC are the DeFond and Park abnormal accruals.

Note: $\mathrm{t}$ value is the parametric t-test results on the difference of mean values and $\mathrm{z}$ value is the nonparametric Wilcoxon $\mathrm{z}$-test on the difference of median values

\begin{tabular}{|c|c|c|}
\hline DAC & $=$ & abnormal accruals \\
\hline Big4 & $=$ & dummy variable, equal to 1 if firm is audited by a big auditor \\
\hline ISALES & $=$ & $\log$ of clients sales in $\$$ millions \\
\hline $\mathrm{CFO}$ & $=$ & operating cash flow for firm I in year t scaled by lagged total assets \\
\hline LEV & $=$ & total liabilities/total assets \\
\hline GROWTH & $=$ & sales growth rate, defined as the sales in year t minus sales in $\mathrm{t}-1$ and scaled by sales in year $\mathrm{t}-1$ \\
\hline$\triangle \mathrm{PPE}$ & $=$ & growth rate of gross property plant and equipment, defined as PPE in year t minus PPE $t-1$ and scaled by PPE t- 1 \\
\hline AG_LOSS & $=$ & dummy variable, equal to 1 if firm reports negative income before extraordinary items in year t-1 \\
\hline
\end{tabular}


Table 3

Results of Regression

Model: $D A C=\alpha_{0}+\beta_{1}$ Big $4+\beta_{2} I S A L E S+\beta_{3} C F O+\beta_{4} L E V+\beta_{5} G R O W T H+\beta_{6} \triangle P P E+\beta_{7} L A G \_L O S S+$ fixed effects $+\varepsilon$

Panel A: U.S. Sample

\begin{tabular}{|c|c|c|c|c|c|c|}
\hline \multirow[b]{2}{*}{ Variables } & \multicolumn{2}{|c|}{ Full U.S. sample } & \multicolumn{2}{|c|}{$\begin{array}{l}\text { Income-decreasing } \\
\text { incentives } \\
(\mathrm{CFO}>\text { prior year } \mathrm{CFO})\end{array}$} & \multicolumn{2}{|c|}{$\begin{array}{l}\text { Income-increasing } \\
\text { incentives } \\
(\mathrm{CFO}<\text { prior year } \mathrm{CFO})\end{array}$} \\
\hline & Estimate & $\mathrm{p}$ value & Estimate & $\mathrm{p}$ value & Estimate & $\mathrm{p}$ value \\
\hline Intercept & -0.008 & 0.140 & -0.072 & 0.000 & 0.039 & 0.000 \\
\hline Big4 & -0.008 & 0.027 & 0.006 & 0.222 & -0.020 & 0.000 \\
\hline ISALES & 0.005 & 0.000 & 0.005 & 0.000 & 0.001 & 0.220 \\
\hline $\mathrm{CFO}$ & -0.241 & 0.000 & -0.154 & 0.000 & -0.098 & 0.000 \\
\hline LEV & -0.013 & 0.000 & -0.011 & 0.001 & -0.004 & 0.315 \\
\hline GROWTH & 0.032 & 0.000 & 0.024 & 0.000 & 0.068 & 0.000 \\
\hline$\triangle \mathrm{PPE}$ & 0.026 & 0.000 & 0.009 & 0.04 & 0.029 & 0.000 \\
\hline LAG_LOSS & -0.011 & 0.000 & 0.025 & 0.000 & 0.007 & 0.039 \\
\hline $\mathrm{N}$ & \multicolumn{2}{|c|}{17757} & \multicolumn{2}{|c|}{8920} & \multicolumn{2}{|c|}{8837} \\
\hline $\mathrm{R} 2$ & \multicolumn{2}{|c|}{0.11} & \multicolumn{2}{|c|}{0.093} & \multicolumn{2}{|c|}{0.114} \\
\hline $\operatorname{adjR} 2$ & \multicolumn{2}{|c|}{0.107} & \multicolumn{2}{|c|}{0.088} & \multicolumn{2}{|c|}{0.110} \\
\hline
\end{tabular}

Panel B: Non-U.S. Sample

\begin{tabular}{|c|c|c|c|c|c|c|}
\hline \multirow[b]{2}{*}{ Variables } & \multicolumn{2}{|c|}{ Full non-U.S. sample } & \multicolumn{2}{|c|}{$\begin{array}{l}\text { Income-decreasing } \\
\text { incentives } \\
(\mathrm{CFO}>\text { prior year } \mathrm{CFO})\end{array}$} & \multicolumn{2}{|c|}{$\begin{array}{l}\text { Income-increasing } \\
\text { incentives } \\
(\mathrm{CFO}<\text { prior year } \mathrm{CFO})\end{array}$} \\
\hline & Estimate & $\mathrm{p}$ value & Estimate & $\mathrm{p}$ value & Estimate & $\mathrm{p}$ value \\
\hline Intercept & 0.010 & 0.004 & -0.057 & 0.000 & 0.046 & 0.000 \\
\hline Big4 & -0.002 & 0.332 & 0.007 & 0.001 & -0.011 & 0.000 \\
\hline ISALES & 0.004 & 0.000 & 0.004 & 0.000 & 0.001 & 0.001 \\
\hline $\mathrm{CFO}$ & -0.373 & 0.000 & -0.230 & 0.000 & -0.196 & 0.000 \\
\hline LEV & -0.011 & 0.000 & -0.019 & 0.000 & 0.000 & 0.963 \\
\hline GROWTH & 0.025 & 0.000 & 0.007 & 0.017 & 0.055 & 0.000 \\
\hline$\triangle \mathrm{PPE}$ & 0.033 & 0.000 & 0.018 & 0.000 & 0.040 & 0.000 \\
\hline LAG_LOSS & -0.022 & 0.000 & 0.013 & 0.000 & 0.000 & 0.916 \\
\hline $\mathrm{N}$ & \multicolumn{2}{|c|}{31557} & \multicolumn{2}{|c|}{15792} & \multicolumn{2}{|c|}{15765} \\
\hline $\mathrm{R} 2$ & \multicolumn{2}{|c|}{0.159} & \multicolumn{2}{|c|}{0.095} & \multicolumn{2}{|c|}{0.112} \\
\hline $\operatorname{adjR2}$ & \multicolumn{2}{|c|}{0.158} & \multicolumn{2}{|c|}{0.092} & \multicolumn{2}{|c|}{0.109} \\
\hline
\end{tabular}

DAC are DeFond and Park abnormal accruals.

Note: $p$ values are two tail and robust to heteroscedasticity and country clustering effects using the method in Rogers (1993)

DAC $=$ abnormal accruals 


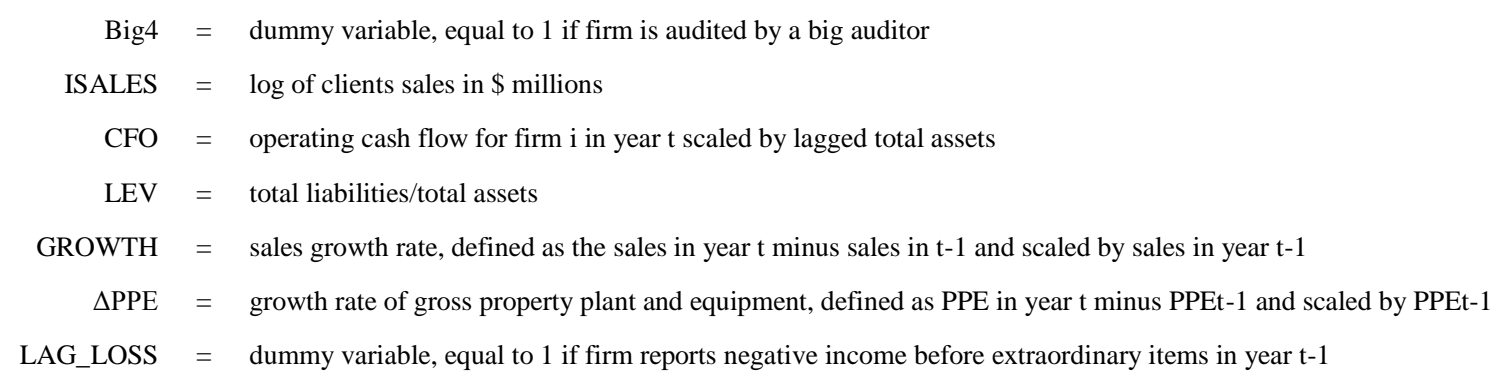

\section{Table 4}

Results of Regression in Strong and Weak Investor Protection Sub-samples

\begin{tabular}{|c|c|c|c|c|c|c|c|c|}
\hline \multirow[b]{3}{*}{ Variable } & \multicolumn{4}{|c|}{ ANTIDIR $>=3$} & \multicolumn{4}{|c|}{ ANTIDIR $<3$} \\
\hline & \multicolumn{2}{|c|}{$\mathrm{CFO}>$ prior year $\mathrm{CFO}$} & \multicolumn{2}{|c|}{$\mathrm{CFO}<$ prior year $\mathrm{CFO}$} & \multicolumn{2}{|c|}{$\mathrm{CFO}>$ prior year $\mathrm{CFO}$} & \multicolumn{2}{|c|}{$\mathrm{CFO}<$ prior year $\mathrm{CFO}$} \\
\hline & Estimate & $\mathrm{p}$ value & Estimate & $\mathrm{p}$ value & Estimate & $\mathrm{p}$ value & Estimate & $\mathrm{p}$ value \\
\hline Big4 & 0.006 & 0.017 & -0.01 & 0.000 & 0.005 & 0.232 & -0.003 & 0.449 \\
\hline $\mathrm{N}$ & \multicolumn{2}{|c|}{11512} & \multicolumn{2}{|c|}{11599} & \multicolumn{2}{|c|}{4280} & \multicolumn{2}{|c|}{4166} \\
\hline $\mathrm{R}^{2}$ & \multicolumn{2}{|c|}{0.104} & \multicolumn{2}{|c|}{0.106} & \multicolumn{2}{|c|}{0.097} & \multicolumn{2}{|c|}{0.152} \\
\hline
\end{tabular}

Note: $\mathrm{p}$ values are two tail and robust to heteroscedasticity and country clustering effects using the method in Rogers (1993). ANTIDIR is the anti-director rights index from La Porta et al. (1998).

\section{Table 5}

Effect of Investor Protection on Earnings Management

\begin{tabular}{|c|c|c|c|c|c|c|}
\hline Model: $D A C=\alpha_{0}+\beta_{1}$ & $4+\beta_{2} I S A L E$ & $\begin{array}{r}+\beta_{3} C F O+\beta \\
\text { effec }\end{array}$ & $\begin{array}{l}E V+\beta_{5} G R \\
+\varepsilon\end{array}$ & $T H+\beta_{6} \Delta I$ & $+\beta_{7} L A G_{-}$ & $S S+$ fixed \\
\hline Panel A: Big Auditor & Clients & & & & & \\
\hline & $\beta_{1}$ & COMMON & ANTIDIR & DISREQ & LITSTD & PUBENF \\
\hline $\begin{array}{l}\text { Income-decreasing } \\
\text { incentives }(\mathrm{CFO}>\text { prior }\end{array}$ & coefficient & 0.012 & 0.004 & 0.017 & 0.013 & 0.008 \\
\hline year CFO) & $\mathrm{p}$ value & 0.000 & 0.000 & 0.002 & 0.001 & 0.123 \\
\hline income-increasing & coefficient & -0.007 & -0.006 & -0.007 & -0.007 & -0.002 \\
\hline incentives $(\mathrm{CFO}<$ prior & & & & & & \\
\hline year CFO) & $\mathrm{p}$ value & 0.001 & 0.000 & 0.191 & 0.072 & 0.751 \\
\hline Panel B: Non-Big Au & itors' Clier & & & & & \\
\hline & $\beta_{1}$ & COMMON & ANTIDIR & DISREQ & LITSTD & PUBENF \\
\hline $\begin{array}{l}\text { Income-decreasing } \\
\text { incentives }(\mathrm{CFO}>\text { prior }\end{array}$ & coefficient & 0.002 & 0.002 & 0.001 & -0.001 & -0.014 \\
\hline year CFO) & $\mathrm{p}$ value & 0.668 & 0.317 & 0.922 & 0.902 & 0.128 \\
\hline income-increasing & coefficient & 0.007 & -0.002 & -0.002 & -0.009 & -0.004 \\
\hline$(\mathrm{CFO}<$ prior year $\mathrm{CFO})$ & $\mathrm{p}$ value & 0.080 & 0.234 & 0.865 & 0.144 & 0.604 \\
\hline
\end{tabular}

To save space, I report only the coefficient on investor protection variables; $\mathrm{p}$ values are two tail and robust to heteroscedasticity and country clustering effects using the method in Rogers (1993).

Variable definitions: 


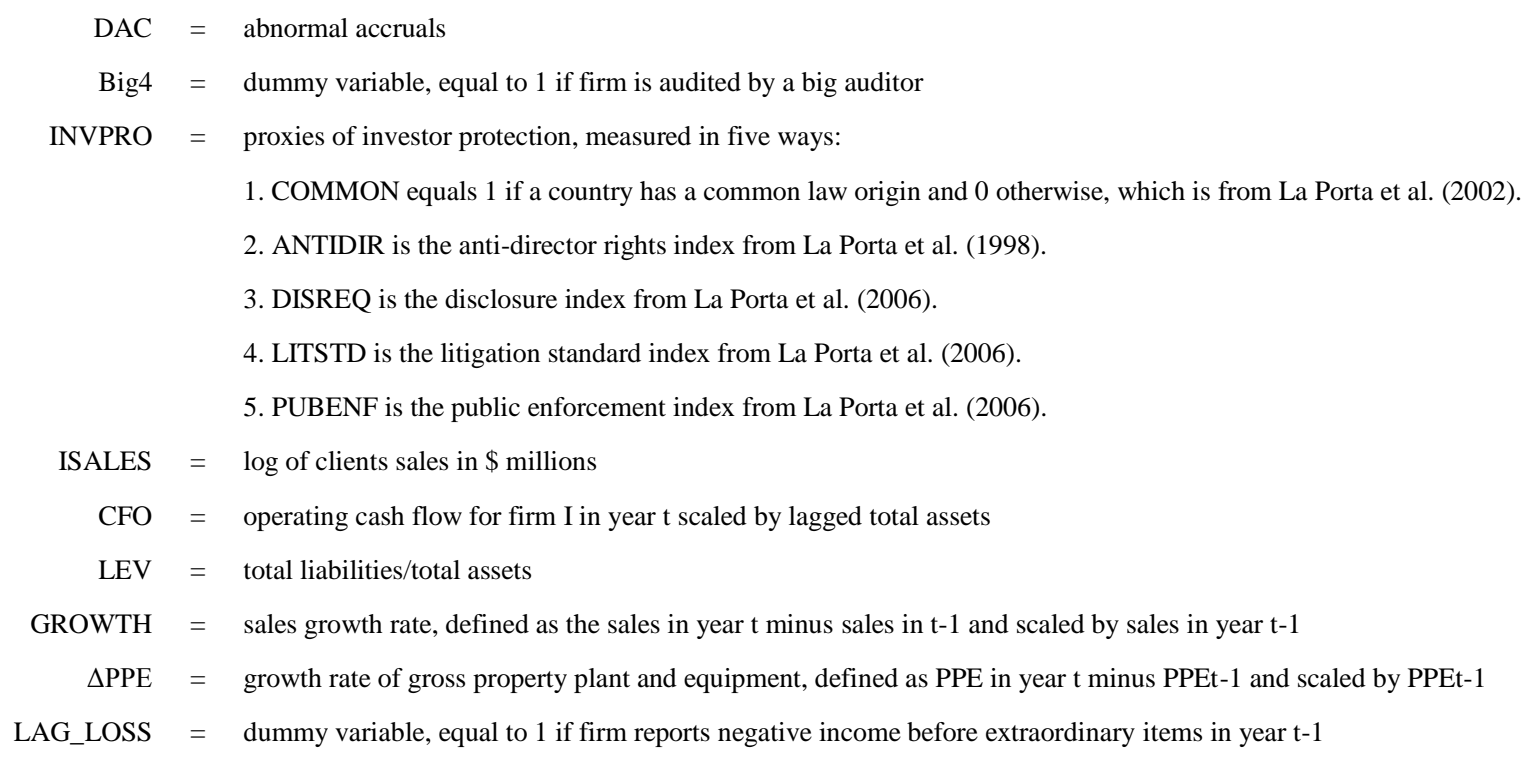

\section{Copyright Disclaimer}

Copyright reserved by the author(s).

This article is an open-access article distributed under the terms and conditions of the Creative Commons Attribution license (http://creativecommons.org/licenses/by/3.0/). 